\title{
Application of analytic element method in hydrogeology
}

\section{Uporaba metode analitičnih elementov v hidrogeologiji}

\author{
Dragan Kaluđerović1,2, Eva Koren ${ }^{3}$, Goran Vižintin ${ }^{3, *}$ \\ ${ }^{1}$ Center for applied scientifical research in water supply and remediation, Serbia \\ ${ }^{2}$ Independent consultant, Serbia \\ ${ }^{3}$ University of Ljubljana, Faculty of Natural Sciences and Engineering, Slovenia \\ * goran.vizintin@guest.arnes.si
}

\begin{abstract}
The analytic element method (AEM) has been successfully used in practice worldwide for many years. This method provides the possibility of fast preliminary quantitative analysis of the hydrogeological systems or boundary conditions of the numerical models, as it is shown in the case study of groundwater source of the city of Vrbas. The AEM is also applicable for the initial analysis of a hydrogeological system, which is of particular importance in case of excess pollution that cannot be predicted where it could happen. One example of the application of the AEM is presented in this article. The analytical model is calibrated based on the measured data from several drilled monitoring wells, and this was the base for the numerical model of the contaminant transport. In this case, the AEM enabled the quick access to information on the hydrogeological system and effective response to excess pollution.
\end{abstract}

Key words: analytical modelling, analytic elements, groundwater flow modelling, mass transport modelling

\section{Povzetek}

Metoda analitičnih elementov se že več let uspešno uporablja v praksi po vsem svetu. Kot je prikazano v študiji primera podzemne vode mesta Vrbas, omogoča ta metoda možnost hitre predhodne kvantitativne analize hidrogeoloških sistemov ali mejnih pogojev za numerične modele. Metoda analitičnih elementov se uporablja tudi za začetno analizo hidrogeološkega sistema, kar je še posebej pomembno v primeru onesnaženj, ki jih ni mogoče predhodno napovedati. $V$ tem prispevku je predstavljen primer uporabe metode analitičnih elementov. Analitični model je kalibriran na podlagi izmerjenih podatkov iz več piezometrov, kar je osnova za numerični model transporta onesnaževalcev. V tem primeru je metoda analitičnih elementov omogočila hiter dostop do informacij o hidrogeološkem sistemu in učinkovit odziv na prekomerno onesnaženje.

Ključne besede: Analitično modeliranje, analitični elementi, model toka podzemne vode, model masnega transporta 


\section{Introduction}

For description of groundwater flow and distribution of the pollution, we have used Darcy's equation and continuity equation. In 1856, the French engineer Henry Darcy conducted research in Dijon. Initially, it was the project of water supplying system that used sand filters. Based on this research and column experiments in the laboratory, he established Darcy's law that describes water flow through sands. It has since been generalised to a variety of situations and is in widespread use today.

For the one-dimensional flow, Darcy's law is represented in the form of equation as:

$$
q_{\mathrm{x}}=-K_{x} \frac{d h}{d x} A
$$

where $q_{\mathrm{x}}$ is the flux in the positive ' $\mathrm{x}$ ' direction (discharge per unit area with units of length per time, $\mathrm{m} / \mathrm{s}$ ), $K_{\mathrm{x}}$ the hydraulic conductivity, $d h / d x$ the hydraulic gradient and $A$ the cross-sectional area to flow. The three-dimensional (3D) flow could also be described using Darcy's law. Darcy's law is valid only for flow in the continuum region where the representative elementary volume (REV) is defined and for laminar flow through the soil. In most of the aquifers, the dimensions of interstices are small and thus the flow is laminar. The other equation that we use to describe groundwater flow is the continuity equation (conservation of mass); the derivation of this equation is available in Fitts [1]. In the ' $x$ ' direction, the equation of conservation of mass is

$$
-\frac{\partial q_{x}}{\partial x}=S_{S} \frac{\partial h}{\partial t}
$$

where $q_{\mathrm{x}}$ is the specific flux (discharge per unit area, with units of length per time, $\mathrm{m} / \mathrm{s}$ ) in the positive ' $x$ ' direction and $S_{s}$ is the specific yield. Using equation (1) in equation (2), we get the equation of the one-dimensional groundwater flow as

$$
\frac{d}{d x}\left(K_{x} \frac{\partial h}{\partial x}\right)=S_{s} \frac{\partial h}{\partial t} .
$$

For 3D flow, the equation is

$$
\begin{aligned}
& \frac{d}{d x}\left(K_{x} \frac{\partial h}{\partial x}\right)+\frac{d}{d y}\left(K_{y} \frac{\partial h}{\partial y}\right) \\
& +\frac{d}{d z}\left(K_{y} \frac{\partial h}{\partial z}\right)=S_{s} \frac{\partial h}{\partial t}
\end{aligned}
$$

For the homogenous and isotropic porous media $\left(K_{\mathrm{x}}=K_{\mathrm{y}}=K_{\mathrm{z}}\right)$, the equation is

$$
\left(\frac{\partial^{2} h}{\partial x^{2}}\right)+\left(\frac{\partial^{2} h}{\partial y^{2}}\right)+\left(\frac{\partial^{2} h}{\partial x^{2}}\right)=\frac{S s}{K} \frac{\partial h}{\partial t} .
$$

If the flow is stationary, equation (5) transforms to

$\Delta h=0$.

Equation (6) is known as Laplace's equation.

Groundwater flow is often presented in hydrogeological models as two dimensional in the horizontal plane, as it spreads wider horizontally than vertically. In this situation also, groundwater flux could be presented as two dimensional, where $h$ varies with $x$ and $y$ axes but not with the $z$ axis. The alternative formulation of the groundwater flow equation may be obtained by invoking the Dupuit-Forchheimer assumption, where it is assumed that heads do not vary in the vertical direction. A horizontal water balance is applied to a long vertical column with area $\delta x \delta y$ extending from the aquifer base to the unsaturated surface. Originally, it is invented for aquifers with atmospheric pressure at the groundwater table, but it could also be used in the case of the artesian aquifers. Derivation of the equation could be found in Fitts [1], and the resulting equation is

$$
\frac{d}{d x}\left(T_{x} \frac{\partial h}{\partial x}\right)+\frac{d}{d y}\left(T_{y} \frac{\partial h}{\partial y}\right)+N=S_{s} \frac{\partial h}{\partial t} .
$$

$N$ represents the addition of water in the vertical direction (recharge). If $T_{\mathrm{x}}=T_{\mathrm{y}}$, the abovementioned equation simplifies to the following form: 


$$
\left(\left(\frac{\partial^{2} h}{\partial x^{2}}\right)+\left(\frac{\partial^{2} h}{\partial y^{2}}\right)\right)+\frac{N}{T}=\frac{S}{T} \frac{\partial h}{\partial t} .
$$

For the stationary groundwater flow, equation (8) transforms into a new form, which is Poisson's equation [1]:

$$
\underline{\Delta} h=-\frac{N}{T} .
$$

\section{Background and methods}

The analytic element method (AEM) [2, 3] uses the technique of superimposing solutions in linear partial differential equations like (9) using the computer, which superimposes a large number of functions. Each analytical element is a mathematical function that is connected with a boundary condition, where an element represents a well, a stream segment or an area of surface recharge. The AEM can be used in one-dimensional, two-dimensional or 3D flow. Equation (7) represents a two-dimensional flow in an isotropic transmissibility. In the AEM, this and other equations are written in form of discharge potential $(\Phi)$. Discharge potential is defined using parameters and groundwater level, so the equations are correct:

$\frac{d \phi}{d x}=T \frac{\partial h}{\partial x} ; \frac{d \phi}{d y}=T \frac{\partial h}{\partial y}$.

Putting this equation into equation (7), we obtain

$$
\Delta \Phi=-N+S_{s} \frac{\partial h}{\partial t} .
$$

Using Laplace's transformation, it is possible to create semi-analytical solution of this nonsteady state equation.

When the flow of groundwater is in the steady state with recharge/leakage, Laplace's equation is

$$
\Delta \Phi=N .
$$

Without recharge/leakage, Laplace's equation is

$\Delta \Phi=0$.

Elementary solutions may be superimposed, which is the main principle of the AEM. This method is used in programme AquiferWin32 Version 5 (developed by the American company Environmental Simulations Inc.); the equations in this programme are based on complex functions of different analytical elements, and they have this form:

Uniform flow:

$\Phi(\mathrm{x}, \mathrm{y})=-\mathrm{Q}_{0}\left(\mathrm{x} \cos \alpha_{\mathrm{u}}+\mathrm{y} \sin \alpha_{\mathrm{u}}\right)+\mathrm{C}$.

Effect of the well:

$\sum_{j=1}^{n} \frac{Q_{j}}{4_{\pi}} \operatorname{In}\left[r_{j}^{2}(x, y)\right]$

Regional recharge:

$$
\begin{aligned}
& -\frac{1}{2}-\frac{N}{a^{2}+b^{2}}\left[\left(a^{2} \sin ^{2} \alpha_{r}+b^{2} \cos ^{2} \alpha_{r}\right)\right. \\
& \left(x-x_{r}\right)^{2}-2\left(a^{2}-b^{2}\right)\left(x-x_{r}\right)\left(y-y_{r}\right) \\
& \sin \alpha_{r} \cos \alpha_{r}\left(a^{2} \cos ^{2} \alpha_{r}+b^{2} \sin ^{2} \alpha_{r}\right) \\
& \left.\left(y-y_{r}\right)^{2}-a^{2} b^{2}\right] .
\end{aligned}
$$

Source/pit - round element:

Equation in the element:

$-\sum_{j=1}^{n} \frac{1}{4}\left[\left(x-x_{p_{j}}\right)^{2}-R_{p_{j}}^{2}\right] N_{p_{j}}$.

Equation outside the element:

$-\sum_{j=1}^{n} \frac{1}{4}\left[R_{p_{j}}^{2} \operatorname{In}\left[\frac{\left(x-x_{p_{j}}\right)^{2}+\left(y+y_{p_{j}}\right)^{2}}{R_{p_{j}}^{2}}\right]\right] N_{p_{j}}$. 
Source/spring - linear element:

$$
\begin{aligned}
& +\sum_{j=1}^{n} \frac{\sigma_{j} L_{j}}{4 \pi} \Re\left\{\left(Z_{j}+1\right) \operatorname{In}\left(Z_{j}+1\right)\right. \\
& \left.-\left(Z_{j}-1\right) \operatorname{In}\left(Z_{j}-1\right) 2 \operatorname{In}\left[\frac{1}{2}\left(\frac{2}{Z_{1}}-\frac{1}{z_{1}}\right)\right]-2\right\}
\end{aligned}
$$

where $\mathrm{x}$ is the $\mathrm{x}$ coordinate of the point for which we calculate the piezometric level (L); $y$ the $x$ coordinate of the point for which we calculate the piezometric level (L); $\mathrm{Q}_{0}$ the volumetric flow rate per unit time/unit width of the aquifer (L2T-1); $\alpha_{u}$ the angle between uniform flow and the $x$ axis, $Q_{1}$ the capacity of the well (L3T-1); $r_{1}$ the distance between the well and the point for which we calculate the piezometric level (L); $\mathrm{N}$ the recharge and net infiltration (LT-1); a the length of a, axis of the ellipse (circle) of recharge (L); $b$ the length of $b$, axis of the ellipse (circle) of recharge (L); $x_{r}$ the $x$ coordinate of the centre of the ellipse (circle) of recharge (L); $y_{r}$ the y coordinate of the centre of the ellipse (circle) of recharge (L); $\alpha_{r}$ the angle between $\mathrm{a}$ and $\mathrm{b}$ axes; $\mathrm{x}_{\mathrm{pj}}$ the $\mathrm{x}$ coordinate of the centre of the circle element (L); $y_{p j}$ the y coordinate of the centre of the circle element (L); $R_{p j}$ the radius of the circle element (L); $\mathrm{N}_{\mathrm{pj}}$ the infiltration of the circular element (LT-1); $\sigma_{j}$ the volumetric flow rate per unit length of the linear element (L2T-1); $\mathrm{L}_{\mathrm{j}}$ the length of the linear element (L); $\mathrm{z}_{1}$ the starting coordinate of the linear element (L) and $\mathrm{z}_{2}$ the final coordinate of the linear element (L).

\section{Discussion and results}

The application and use of the AEM is different than the application of the classic numerical method. Here, we have represented a few fundamental differences. This method is analytical, and there are no errors caused by the numerical approximation of the partial differential equation [4]. The solution derived with this method is not sensitive to the scale of the domain [5], which varies from few tens of metres to several tens of kilometres. The boundary conditions do not influence the accuracy of the solution, ex- cept right at the boundary where the boundary condition approximation depends on the scale of elements and the degrees of freedom in each element. The biggest limitation of the analytic element method as used in AquiferWin32 is that it simulates only steady-state conditions. In the area of Vrbas city and below it, there are two aquifers, one shallow up to $70 \mathrm{~m}$ deep and the second deeper at a depth of approximately $120 \mathrm{~m}$. In this model, the shallower aquifer was simulated; the reason for application of analytic element modelling is that the shallow aquifer was covering a huge area, more than $100 \mathrm{~km}$, and therefore it would be very hard to get physical boundaries of the numerical model. In the AquiferWin32, the model was simulated as a single-layer, homogenous aquifer with fully penetrating elements. Set points of the elevation of the bedrock and the aquifer overlying units were averaged to 17 and 65 a.m.s.l., while the starting value of the hydraulic conductivity was $1.6 \times 10^{-4} \mathrm{~ms}^{-1}$.

Measurements of head in July 1996 in ten piezometers were used to calibrate the model. Small precipitation is a characteristic for this month, as well as the month before and after, and it could be assumed that net infiltration is minimal or none. In this period, the first aquifer was tapped by several wells, a well on the pig farm (5 l/s), well B-10 nearby the existing source in Vrbas (12 l/s), a well at the gravel exploitation location $(4 \mathrm{l} / \mathrm{s})$ and a source in Kula $(\sim 0 \mathrm{l} / \mathrm{s})$, which were represented as analytical elements of wells.

Based on the geotechnical research documentation, it is determined that bottom of the channel DTD is curved in aquifer sands, so the water level in the channel south from the Savino village is represented with two line elements with constant head 79.75 and 79.65 a. m. s. l.

AquiferWin32 and many AEM programmes require input of a groundwater level at one point - that is the reference point, a point with a specified water level regardless of other conditions. The reference point was positioned in the piezometer PP-7, and the value of the groundwater level was 79.01 a.m.s.l., taken as the reference level. This piezometer is chosen as it is positioned far from the influence of well exploitation, which is one of the primary requirements for the selection of the reference point. The gen- 


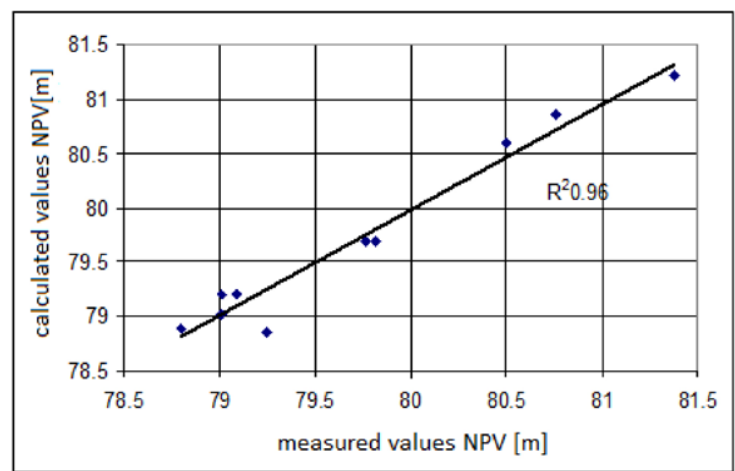

Figure 1: "Scatter" diagram of measured and calculated groundwater levels.

eral direction of groundwater flow is taken as $75^{\circ}$, measured in the clockwise direction relative to east, with a gradient of $1 \times 10^{-4}$.

These piezometers were used in model calibration: PP-2, PP-3, PP-5, PP-7, PP-9, PD-2, PD-3, Ekonomija, Prečistač and Vojin Salaš (Figure 1). The first step of calibrating the model was setting the azimuth of the regional groundwater flow, and the best result was for the value of $63^{\circ}$. The other parameter that was modified during the calibration was the regional gradient, and the best result was for the gradient value of $2.9 \times 10^{-4}$. Changing the elevation of the top and bottom of the aquifer did not show a big influence on the model results, so the input average values were kept. Minimal declination from measured values was for the hydraulic conductivity of $1.7 \times 10^{-4} \mathrm{~ms}^{-1}$, and this value was used in the further simulation.

Further improvement of model results came by including the evapotranspiration as a negative vertical balance. The groundwater level in the first aquifer is supposed to be very shallow, close to the ground surface ( $3 \mathrm{~m}$ deep), and the hydraulic connection between groundwater and the "non-permeable" layer exists, so it is possible that the aquifer loses the water by evapotranspiration through this layer. These discharge zones are presented with circular area sink elements and determined based on the comparison of terrine elevation maps and groundwater level maps. Zones with shallower groundwater levels are represented with smaller circle elements, which is a way of discretisation. The smaller elements work with more intensity comparing to bigger circle ele-

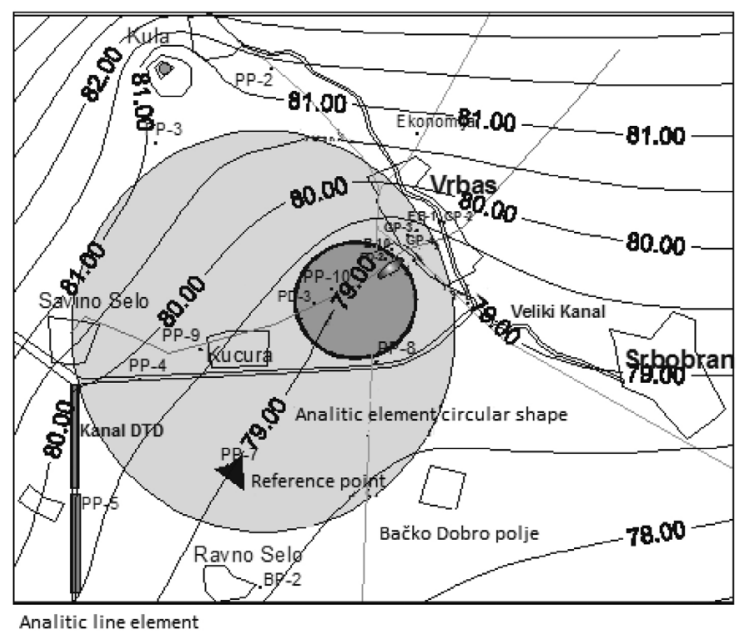

Figure 2: The map of isolines of groundwater levels stationary condition (June 1996) 1:200000.

ments. The process of adjusting the model was finished when measured levels in piezometers and calculated levels were acceptably close to each other (Figure 1). The isolines of groundwater heads of this model are given in Figure 2. The absolute mean residual value is $0.014 \mathrm{~m}$ for all 10 calibration targets; the only bigger deviation is registered on the piezometer PD-2, while other piezometers had small residuals. The causes of the deviation on PD-2 are unknown but may be due to incorrect schematisation, the effects of transient flow in the model or measuring mistakes. The deviation values do not differ that much, so it could be said that the model is well calibrated.

The analytic elements in the simulation are as follows:

- The channel south from the Savino village is presented as two line elements with a constant level, and these analytical elements participate with $11 \mathrm{l} / \mathrm{s}$ as a groundwater source.

- Circular analytic element already represents the evapotranspiration, with a surface area of $1.38 \times 108 \mathrm{~m}^{2}$; the discharge flow got by model calibration is $1.5 \times 10^{-10} \mathrm{~ms}^{-1}$, and it participates in the balance with $20.7 \mathrm{l} / \mathrm{s}$.

- Circular analytic element, smaller but with a bigger capacity (intensity), represents stronger evapotranspiration (groundwater level closer to the surface); the surface area is $2 \times 107 \mathrm{~m}^{2}$, and the calibrated in- 
tensity is $6 \times 10^{-10} \mathrm{~ms}^{-1}$; it participates in the balance with $12 \mathrm{l} / \mathrm{s}$.

- Wells, point elements, work with the capacities that were previously mentioned.

In Figure 3, the nature of the method is shown, and it could be seen that the model has no boundaries, so the solution is valid only for the research area.

Analysing sensitivity, for the purpose of uncertainty of the calibrated model, showed that the smallest differences are caused by changing the elevation values of top and bottom of the aquifer. These values were changed by $\pm 50 \%$ of the values accepted at the beginning, and this range represents the upper and the lower elevation values, got by drilling in the research area, so this parameter does not influence much to the solution of this system.

Changes in the statistical calibrating parameters, during the change in the hydraulic conductivity, show bigger response of the results and nonlinearity, i.e. smaller values of the hydraulic conductivity, and cause bigger errors than big values. Input data related to the reference point showed different responses. Changing the azimuth values of the groundwater flow caused small influence to piezometer levels, probably because the levels are fixed by other analytical elements. Sensitivity of the model resulting to changes in the gradient values of the reference point was noticeably higher than that in case of other parameters.

Changes in the evapotranspiration intensity (by changing only the values of bigger analytical elements, because changes in the smaller ones have only the local influence) had a relatively weak influence on the piezometer level. Instead of measuring this parameter, like other elements were measured, values obtained for this parameter were empirical, and values of the intensity were obtained by calibration. It could be concluded that values of the evapotranspiration are the most uncertain.

It is important to mention that statistical parameters that indicate the success of calibration obtain their minimum values of the representative input data, and we can use these values for the verification of the success of the calibrating process.

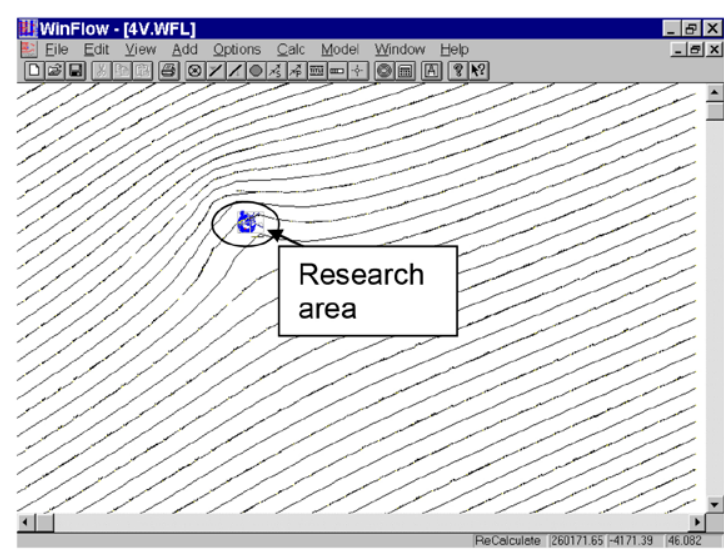

Figure 3: Display of the domain without boundaries in which one part is the research area.

\section{Evaluation of the impact of oil spill on the environment and aquifer, conducted in two phases}

Owing to intentional damage of the pipeline caused by an unidentified person at the chainage 14.5 of the Novi Sad (Pancevo's pipeline), crude oil leaked from the pipeline to the environment. The estimated crude oil leakage was $\sim 54,596 \mathrm{~kg}$. The contaminated site is located on the cadastral plot number 4248 of the local municipality of Kovilj, which is the property of "Vojvodinaput - Backaput" enterprise from Novi Sad. This location was used as the sand excavation site for constructing the Kovilj traffic loop on the Belgrade-Novi Sad highway. The depth of the depression was 3-5 m, which made the accident location difficult to access. The surveys were done in order to contour the pollution, and the mathematical model of the contaminant transport was made based on those surveys.

In general, there are two methods to solve the problem of groundwater flow and transport of the pollution in them: analytical method and numerical method. The main limitation of analytical models is their ability to solve only simple problems; obtaining very precise solutions is their main advantage. However, numerical models are used for simulations in complex surroundings. Numerical models make it possible to replace continual forms of partial differential equations with the final number of algebraic equations, and this procedure provides 
Table 1: Measured and computed groundwater heads.

\begin{tabular}{cccc} 
Target head (m) & Computed head (m) & Residual (m) & Well name \\
\hline 75.730003 & 75.786697 & 0.056694 & PZ-1 \\
\hline 75.900002 & 75.872733 & 0.027269 & PZ-2 \\
\hline 75.839996 & 75.876975 & 0.036979 & PZ-3 \\
\hline 76.070000 & 76.068621 & 0.001379 & PZ-5 \\
\hline 76.019997 & 76.040388 & 0.020392 & \\
\hline
\end{tabular}

the simulations of the systems with irregular special and temporal characteristics.

\section{Mathematical modelling using the AEM - the first phase in modelling}

As the first step in mathematical modelling, the AquiferWIN32 Version 5 programme, developed by the North American Company Environmental Simulations Inc., was used. This programme enables simulation of groundwater flow using the AEM in the 2D horizontal plane. The basis of this method is superposition of influences of analytical elements of different shapes and function of regional gradient of groundwater. Although limited to steady-state flow, this method provides a fast and efficient analysis of a hydrogeologic system, which is of particular importance in the early stage of investigation when data are scarce.

The programme simulates effects of the following analytical elements: wells, uniform recharge of the entire model surface, circular elements, recharging/discharging wells and linear elements that can be either sinks or sources of water. The number of elements in the model is not limited and depends solely on the computer memory.

\section{Entry data}

On the basis of lithological profile that was made on six drilled piezometers at top and bottom of the layer, average input points of 77 and $57 \mathrm{mnm}$ were chosen. Although it is clear that top and bottom of the layer vary (the bottom point is not positively determined due to shallow drills, $\sim 5 \mathrm{~m}$ ), the limitations of this meth-

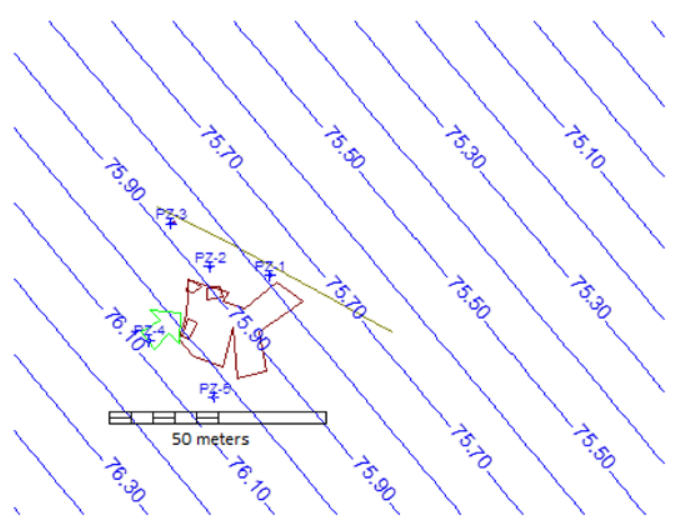

Figure 4: The isolines of groundwater heads in the research area of the calibrated model.

od demanded the use of constant values. Initial hydraulic conductivity $K$ taken for this model is $1 \times 10^{-4} \mathrm{~m} / \mathrm{s}$, and it was obtained from the data in the literature. It is necessary to mention that sieve analysis gave considerably smaller hydraulic conductivity value and that, determined in this way, it is on the border of certainty. Groundwater head measurements in piezometers (5), done throughout November 2013 (Table 1), served for calibration of the model. In AEM, it is necessary to know the value of piezometric heads at one point - the reference point, which serves as a starting value for calculation in which the level remains constant throughout the simulation. The reference point is put into the piezometer PZ-4, and the measured piezometric level is $76.07 \mathrm{mnm}$.

By changing the values of the regional gradient, groundwater flow direction and the mentioned parameters, the results were obtained with minor residuals between the measured and computed levels of groundwater (Figure 4).

In the course of calibration, the model demonstrated the highest level of sensitivity to the 
Table 2: Measured and computed groundwater heads, December 2013.

\begin{tabular}{cccc} 
Target head (m) & Computed head (m) & Residual (m) & Well name \\
\hline 75.66 & 75.821607 & -0.16160 & PZ-1 \\
\hline 75.82 & 75.867556 & -0.04755 & PZ-2 \\
\hline 75.74 & 75.856221 & -0.11622 & PZ-3 \\
\hline 76.00 & 76.000148 & -0.00014 & PZ-4 \\
\hline 75.95 & 76.002048 & -0.05204 & PZ-5 \\
\hline 75.62 & 75.529781 & +0.09021 & PZ-6 \\
\hline 75.82 & 75.895146 & -0.07514 & PZ-7 \\
\hline 75.70 & 75.684449 & +0.01555 & PZ-8 \\
\hline
\end{tabular}

\section{Comment on the model results}

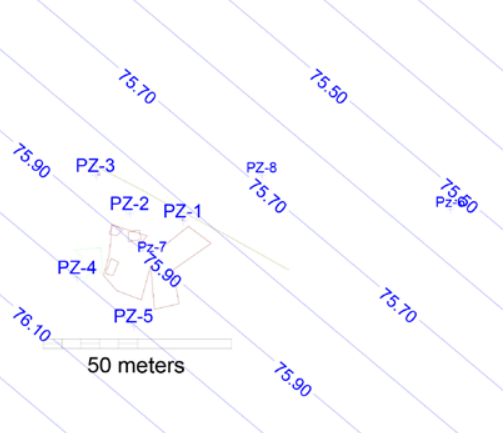

Figure 5: The isolines of the groundwater heads in the research area of the calibrated model, December 2013.

changes in the values of the regional gradient of the groundwater from 0.01 to 0.001 , while the correspondent absolute residual mean (ARM) values varied from 0.67 to 0.042 . The gradient value of 0.009 was selected at the end of calibration because it produced the smallest error. Besides, the azimuth of the groundwater flow was changed; $40^{\circ}$ was selected, and it demonstrated less sensitivity than the regional gradient.

As a confirmation of the analytic model results, another round of measuring was carried out in December 2013 on eight piezometers (Table 2 and Figure 5), and the model was calibrated. The results were slightly different; the gradient was 0.006 , while azimuth of the groundwater flow was $50^{\circ}$ (Figure 5). The results are logical and comply to the previous measuring (Table 2).
Although it is obvious that this is a simplified simulation, the calibration results are good. All eight piezometers were well calibrated, which is an excellent result. The results obtained in this way will be used as a basis to come to the boundary conditions of the 2D numerical model of contaminant transport where the spreading of pollution within the aquifer is to be researched.

\section{Numerical model of the contaminant transport in the research area}

The boundary conditions from the previous model, obtained using AEM with the help of AquiferWin 32 programme, were used as a basis for the 2D numerical model of contaminant transport. The model was practically copied, only this time to the numerical model. The programme used for simulation was MT3DMS [6] and graphic interface was Groundwater Vistas, Version 6 [7], developed by the North American Company Environmental Simulations Inc. The formed 2D numerical model had the same parameters as the model done using AEM, but now discretisation was done with $183 \times 141$ columns and rows (Figure 6). In the part necessitating higher precision, the cell size was $2 \times 2 \mathrm{~m}$ and the total number of cells was 25803. For the values of dispersivity, the following values were given: $5 \mathrm{~m}$ for longitudi- 


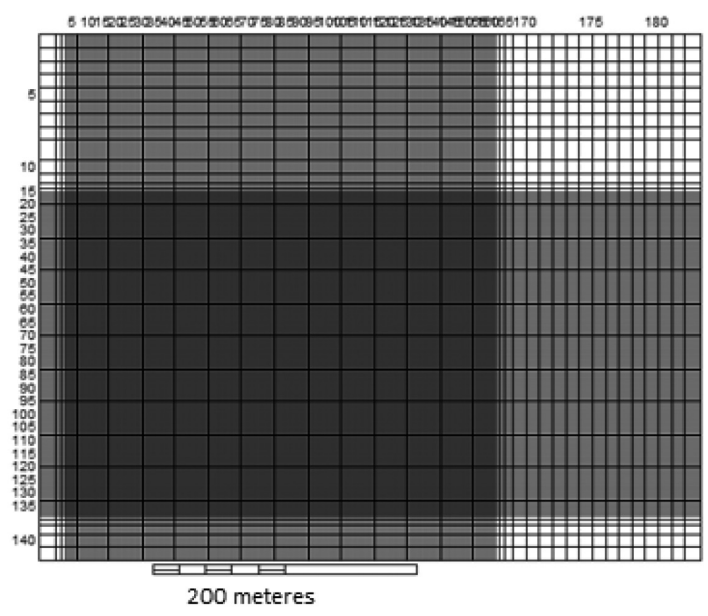

Figure 6: Presentation and discretisation of the model. nal dispersivity and $0.5 \mathrm{~m}$ for transversal dispersivity. These values have been taken from the literature. The taken value for porosity was $\mathrm{h}=0.2$. The simulation (Figure 7) was done using the literature data for benzene. Benzene was taken as a very soluble contaminant difficult to absorb, and therefore, it is a good choice to simulate. In this simulation, benzene adsorption coefficient $\left(K_{\mathrm{d}}\right)$ is $1.52 \mathrm{l} / \mathrm{mg}$ and volume density is equal to $1600 \mathrm{~kg} / \mathrm{m}^{3}$.

The value for the distribution coefficient $K_{\mathrm{d}}$ was taken from the literature [8-10]. Half-life biodegradation value was also included in the simulation to simulate biodegradation, and it was $\mathrm{t}_{1 / 2}=407.5$ days, also taken from the literature $[11,12]$. After 10 years of simulation, the benzene spread out at $2300 \mathrm{~m}$ (Figure 7) from the source of contamination, at the place where oil was spilt. The well near the threshing barn was not endangered, which was one of the goals of this simulation - to estimate an environmental impact to well from oil spill.

\section{Conclusions}

To estimate the spreading of the pollution dissolved in the groundwater, a simple 2D model was constructed. Naturally, more data would be needed for more precise results (such as monitoring of the groundwater level in the course of one hydrologic year) although the results with parameters at the boundary of certainty demonstrate that receptors are not endangered

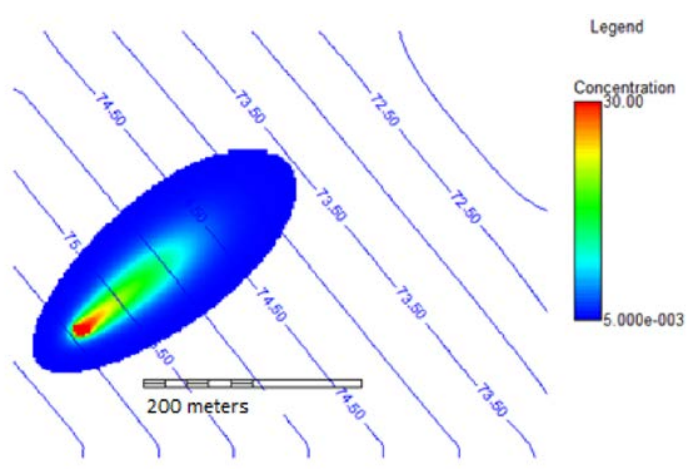

Figure 7: Surface of the model that is covered with concentrations of up to $0.005 \mathrm{mg} / \mathrm{l}$ after 10 years of simulation with advection, dispersion, adsorption and biodegradation. The characteristic contaminant is benzene.

and that the application of the natural remediation of the aquifer is possible.

Use and application of the AEMs significantly differ from the application of numerical methods. Several fundamental differences are mentioned here. The method is analytical, and discretisation of the domain of interest is not a necessity; just because of this, there are no errors due to the model resolution, i.e. due to the numerical approximation of the partial differential equation, which is used for the simulation of the groundwater flow. The solution acquired in this method is not sensitive to the scale of the model, which can range between a couple of dozens of metres and a couple of dozens of kilometres. The schematised aquifer simulated in this analytical method is unlimited in plan; boundary conditions cannot influence the accuracy of the solution. Various analytical elements enable simulation of relatively complex systems, and the solution of the entire system is obtained by superposition of all analytical elements. The biggest limitation of the AEM is its capacity to simulate only steady conditions of the groundwater flow. This shortcoming of the method also has some positive sides; for simulation in unsteady conditions, additional input data (specific yield, starting conditions) are needed, and at the same time, such simulations are considerably more complex to perform. The analytic element model is an ideal tool for researching in accidental pollutions when it is necessary to react swiftly and data are scarce. 


\section{References}

[1] Fitts, C. (2012): Groundwater Science, Second Edition, Elsevier: Amsterdam, 692 p.

[2] Haitjema, H.M. (1995): Analytic element modeling of groundwater flow. Academic Press: San Diego, 407 p.

[3] Strack, O.D.L. (1999): Principles of the analytic element method. Journal of Hydrology, 226(3), pp. 128-138.

[4] Hsiao, C., Chang, L. (2002): Dynamic Optimal Groundwater Management with Inclusion of Fixed Costs. Journal of Water Resources Planning and Management, 128(1), pp. 57-65.

[5] David, R.S., Bernard, E.A. (2006): The Synergistic Powers of AEM and GIS Geodatabase Models in Water Resources Studies. Groundwater, 44(1), pp. 56-61.

[6] Zheng, C., Wang, P. (1999): MT3DMS: A Modular Three-Dimensional Multispecies Transport Model for Simulation of Advection, Dispersion, and Chemical Reactions of Contaminants in Groundwater Systems; Documentation and User's Guide. U.S. Army Corps of Engineers, U.S. Army Engineer Research and Development Center; Vicksburg, Mississippi.
[7] Environmental Simulation incorporated, 2014: Groundwater Vistas 6, USA.

[8] Hunt, J.R., Nicholas, S., Udell, K.S. (1988): Non aqueous phase liquid transport and cleanup 1 . Analysis of Mechanisms. Water Resources Research, 24(8), pp. 1247-1258.

[9] Ling, M., Rifai, H.S. (2007): Modeling Natural Attenuation with Source Control at a Dry-Cleaner Site. Groundwater Monitoring Review and Remediation, 27(1), pp. 108-121.

[10] Miller, C.T., Poirier-McNeill, M.M., Mayer, A.S. (1990): Dissolution of trapped nonaqueous phase liquids: Mass transfer characteristics. Water Resources Research, 26(11), pp. 2783-2796.

[11] Brauner, J.S., Widdowson, M.A. (2001): Numerical simulation of a natural attenuation experiment with pertoleum hydrocarbon NAPL source. Ground Water, 39(6), pp. 939-952.

[12] Howard, P.H., Boethling, R.S., Jarvis, W.F. Meylan, W.M., Michalenko, E.M. (1991): Handbook of Environmental Degradation Rates. Lewis Publishers Inc.: Chelsea, Michigan, 725 p. 